\title{
Multivariate erosion risk assessment of lateritic badlands of Birbhum (West Bengal, India): A case study
}

\author{
Sandipan Ghosh* and Kamala Bhattacharya \\ Post-Graduate Dept. of Geography, The University of Burdwan, Burdwan 713 104, West Bengal, India. \\ *Corresponding author. e-mail: sandipanghosh19@gmail.com
}

Each geomorphic hazard involves a degree of risk which incorporates quantification of the probability that a hazard will be harmful. At present, the categorization of sub-watersheds into erosion risk is considered as the fundamental step to conserve the soil loss. Development of badlands over the laterites of Birbhum district is an indicative of excessive soil loss in the monsoonal wet-dry type of climate. Slope erosion and channel erosion have generated huge amount of sediment from the small watersheds during intense monsoonal rainfall (June-September). The adjoining areas of Rampurhat I Block, Birbhum (West Bengal) and Shikaripara Block, Dumka (Jharkhand) have lost the lateritic soil cover at a rate of 20-40 ton/ha/year (Sarkar et al. 2005). In order to estimate the progressive removal of soil particles from the gully-catchments of the above-mentioned area, different morphometric parameters, soil parameters, hydrologic parameters and empirical models are employed. Side by side, the study is carried out to categorize the gully-catchments into different magnitude of erosion risk using several multivariate statistical techniques.

\section{Introduction}

Fluvial erosion is the composite result of several hydro-geomorphic processes (e.g., overland flow, rill and gully erosion) whereby debris, soil and rock materials are loosened or dissolved and removed from any part of the earth's surface (Kirkby 1969a; Stoddart 1969). In general, 'soil erosion' is a twophase process consisting of the detachment of individual particles from soil mass (by rainsplash erosion) and their transport by erosion agents such as running water (overland flow). When sufficient energy is no longer available to transport the particles, deposition occurs (Morgan 2005). Soil erosion is a function of erosivity (i.e., potential ability of falling raindrops to detach soil particles) and erodibility (i.e., the degree to which soil particles is susceptible to erosion by water) (Hudson 1984). As the raindrops, rills and gullies are the chief agents of catchment erosion or suspended sediment yield; the early phase of soil erosion study should incorporate the quantitative basin-oriented or catchmentoriented approach (Chorley 1969; Jha and Paudel 2010). Then to control the erosion or to take erosion protection measures, the fundamental step is to assess the present severity or risk of catchment erosion through the hydro-geomorphic quantitative expressions and thematic maps. A geomorphic hazard, like soil erosion, involves a degree of risk, the elements at risk being land property, loss of top-soil, soil infertility and the environment (Bell 1999; Blinkov and Kostadinov 2010). 'Risk' involves quantification of the probability that a hazard will be harmful and the tolerable degree of risk depends upon what is being risked, soil conservation being much more important than land utilization (Bell 1999). 'The assessment of erosion hazard' is a specialized form of land resource

Keywords. Erosion risk; soil erosion; sediment yield; multivariate analysis; GIS. 
evaluation, aiming categorization or ranking of land areas and catchments of the study area into regions of low to high erosion risk zones based on selected hydrologic, geomorphic and soil parameters (Sarkar et al. 2005). Side by side, analyzing the regional climatic pattern, rainfall erosivity, overland flow and using several multivariate statistical techniques, we have identified sequentially those influencing parameters or factors which enhance significantly the catchment erosional processes of area under study and at last we have prepared the catchments' priority for soil conservation (in terms of controlling the factors of soil erosion).

\section{Methodology}

Erosion risk assessment always demands an interdisciplinary approach connecting the disciplines of hydrology, geomorphology and pedology (Gerrard 1981; Jha and Kapat 2009). It stresses predominantly on the quantitative method, incorporating the statistical and mathematical equations to analyse phenomena. The present study includes three principal processes - empirical observations, recording of data and quantitative interpretation. The adopted methodology is clearly represented in a flowchart (figure 1). The ultimate aim of this study is to recognize those catchments of gullies where the soil productivity, land uses and land covers are threatened by excessive soil loss by water.
To reach that goal the following objectives are taken into consideration:

- Understanding the geo-environmental settings of the study area which influence both rainfall erosivity and soil erodibility;

- Analyzing statistically the relations of hydrogeomorphic parameters with erosion of selected catchments;

- Multivariate analysis of those parameters to identify the dominant or principal parameters and relative clustering of catchments in terms of components' scores; and

- Classifying the sample catchments from low to high erosion risk and mapping the potential erosivity and soil erosion of the study area.

Here the catchments or drainage basins of 2 nd and 3rd order and slope facets are taken as an ideal geomorphic unit. The study area is subdivided into 17 catchments for the detailed erosional study. In the pre-field session, topographical sheet (72 P/12/NE, 1979), District Resource Map of Birbhum District (Geological Survey of India 2001), climatic data of India Meteorological Department and Irrigation and Waterways Department of West Bengal, satellite images (LANDSAT and IRS), SRTM data (2006), numerous literatures, bulletins and reports are collected. The spatial information is stored in Geographic Information System (GIS) and the thematic maps are prepared using GIS software (ArcGIS 9.2 and 21st Century GIS). The

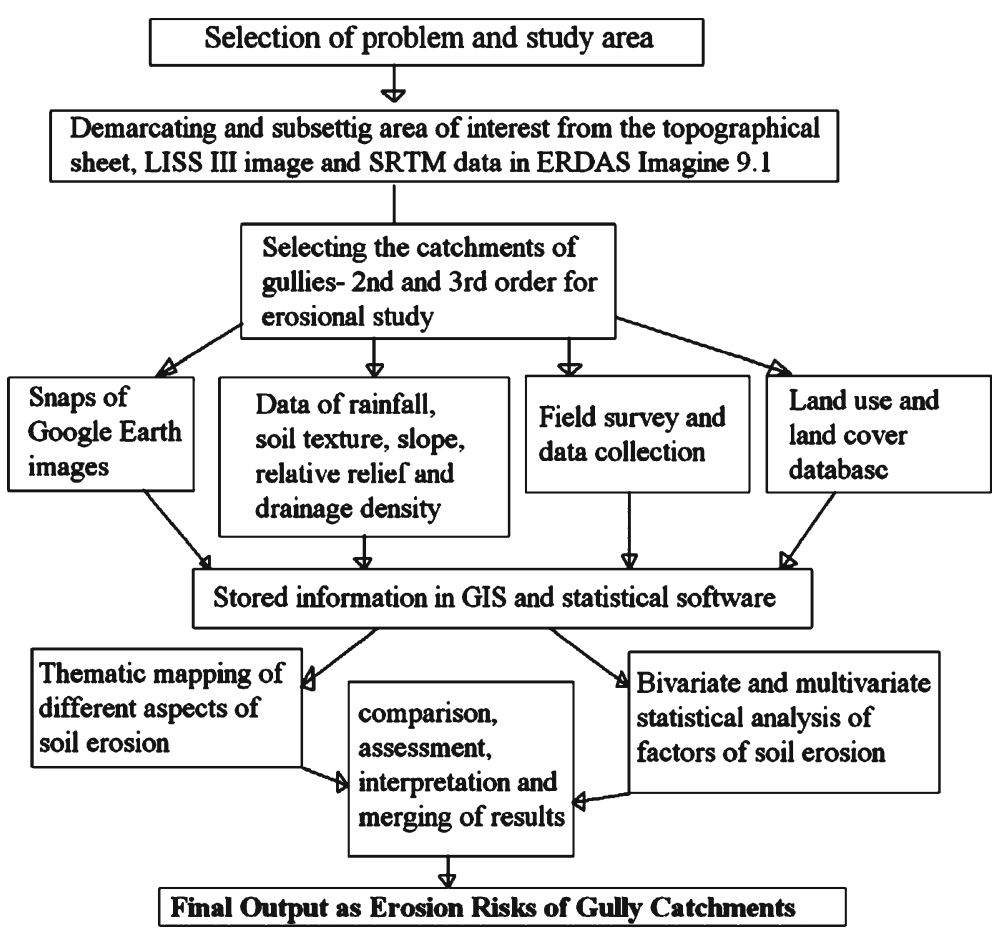

Figure 1. Flow chart of methodology adopted in this study. 
different statistical analysis (e.g., linear and curvilinear regression, correlation, principal component analysis, cluster analysis and multiple regressions) is done in Microsoft Excel 2003 and SPSS 14.0 softwares.

The selected study area $\left(65.84 \mathrm{~km}^{2}\right)$ is situated between the adjoining area of western Rampurhat, I Block of Birbhum district, West Bengal and eastern Shikaripara Block of Dumka district, Jharkhand. The study area is located at $5 \mathrm{~km}$ west of Rampurhat railway station, near Baramasia bus-stop. The latitudinal extension ranges from $24^{\circ} 10^{\prime} \mathrm{N}$ to $24^{\circ} 13^{\prime} \mathrm{N}$ and longitudinal extension ranges from $87^{\circ} 39^{\prime} \mathrm{E}$ to $87^{\circ} 45^{\prime} \mathrm{E}$ (figure 2). It is the lateritic elevated interfluve portion (mean relief of 56 metre) of Brahmani (north) and Dwarka (south) rivers. The laterites and lateritic soils of Cainozoic Era are found here over Rajmahal Trap-Basalt of Jurassic to Cretaceous Period (Hundy and Banerjee 1967; Sarkar et al. 2007). The detrital laterites are occurred here in loose concretions as gravels and pebbles and these are generally derived from weathered primary high-level laterites by fluvial processes and are deposited far from their source of origin (Rajmahal Highlands). Laterites are generally underlain by lithomergic clays which is more prone to tunnel erosion (soil piping) (Jha and Kapat 2009).
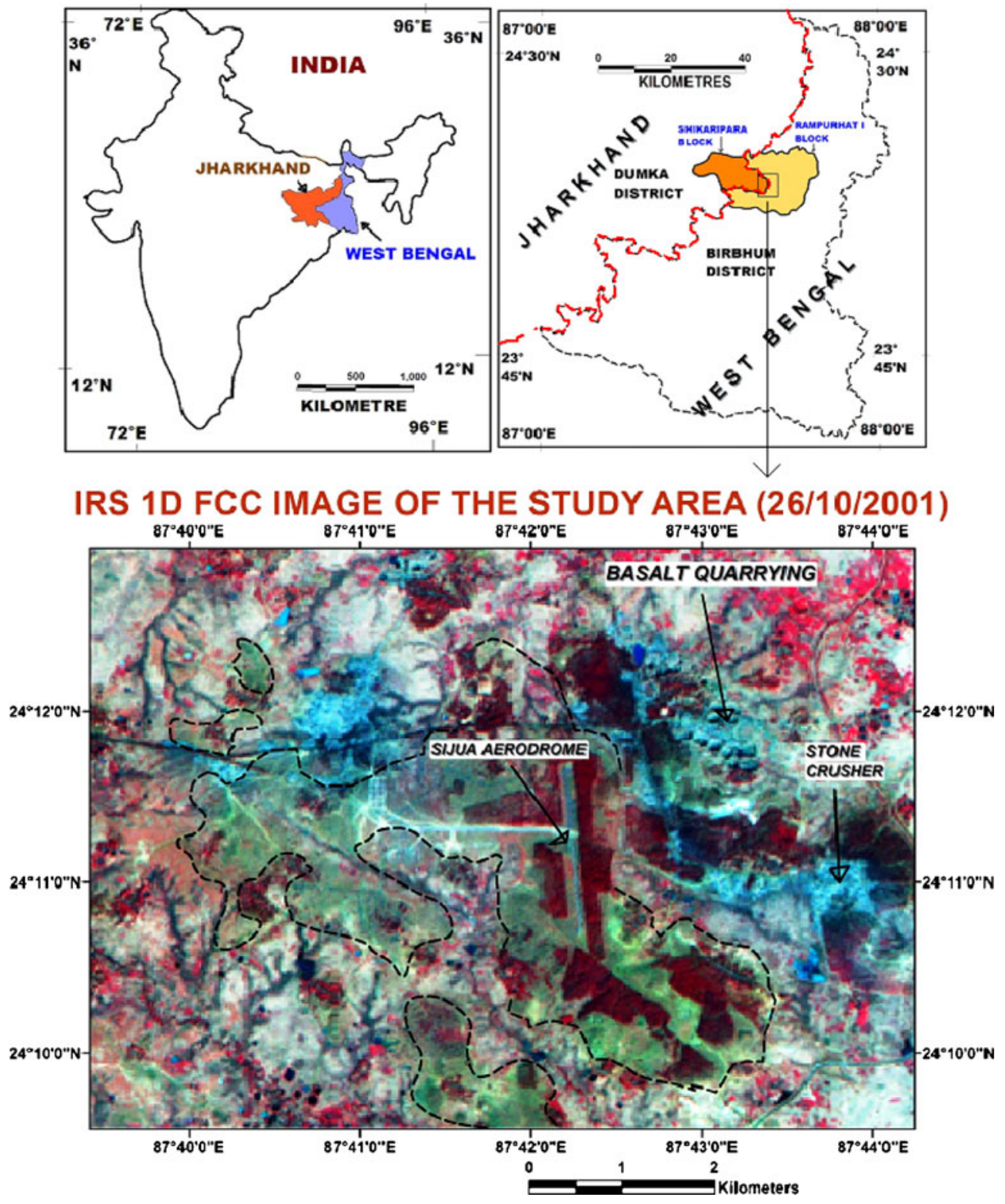

Figure 2. Location map of the study area. 


\section{Severity of soil erosion and role of climatic variables}

The movement of water on catchment occurs in two ways to enhance soil loss (Abrahams 1964; Morisawa 1985):

(1) Rainfall on the surface of a watershed can be removed by infiltration into the soil or rock, by sheet flow over the surface/or by flow through a system of rills, gullies or stream channels; and

(2) The sub-surface water may remove material in solution or suspension as it flows, resulting in a subsurface system of 'pipes'. Piping (or sapping) may eventually result in open rills or gullies when the roofs of these tunnels collapse.

Based on the topographical sheet (1979), IRS 1D LISS III image (2001), Google Earth (2007) and field survey (2010), the current geographical area of forest, degraded lateritic land and stone quarrying are $3.95,16.23$ and $2.9 \mathrm{~km}^{2}$, respectively. From the recurrent field investigations, following important facts regarding magnitude of erosion risk have come into light.

(i) The severity of erosion can be understood by the appearances of numerous rills and gullies, exposure of tree roots, pedestal erosion, pinnacle erosion, bare soil cover, barren waste land, tunnels and surface crusting (figure 3);

(ii) Monsoonal wet-dry type of climate has high seasonal regime which influences laterisation and soil loss (McFarlane 1976);

(iii) Due to high erodibility of lateritic soil (20-40 t/ha/y), deforestation, morum and stone quarrying, low water holding capacity $(<50 \mathrm{~mm} / \mathrm{m})$, low clay content $(<25 \%)$ and organic carbon $(<1.5 \%)$ of soil favour surface and sub-surface erosion;

(iv) Rainsplash erosion is more effective in the upstream deforested area of catchment than overland flow;

(v) Horton overland flow and saturation overland flow both occur in heavy showers of summer thunderstorms and monsoon and it transports downslope clay and silt from topsoil and leave the coarse sand and gravels in upslope (Kirkby 1969b);

(vi) Breaks in vegetation cover, bareness of soil, local irregularities on slope, surface run-off, etc. develop rills and gullies at some distance from the water divide and the system of rills becomes true drainage net by abstraction and micropiracy (Parsons 2005);

(vii) Diversion of the overland flow into large rill increases its erosive and grading ability and that rill may become enlarged enough to be called as a gully. Though gully heads are formed by saturation overland flow, collapsing of tunnels and soil slumping; and

(viii) Such a gully in turn develops rills on its valley walls which by the processes of micropiracy and cross-grading become tributaries (figure $3 \mathrm{a}$ ).

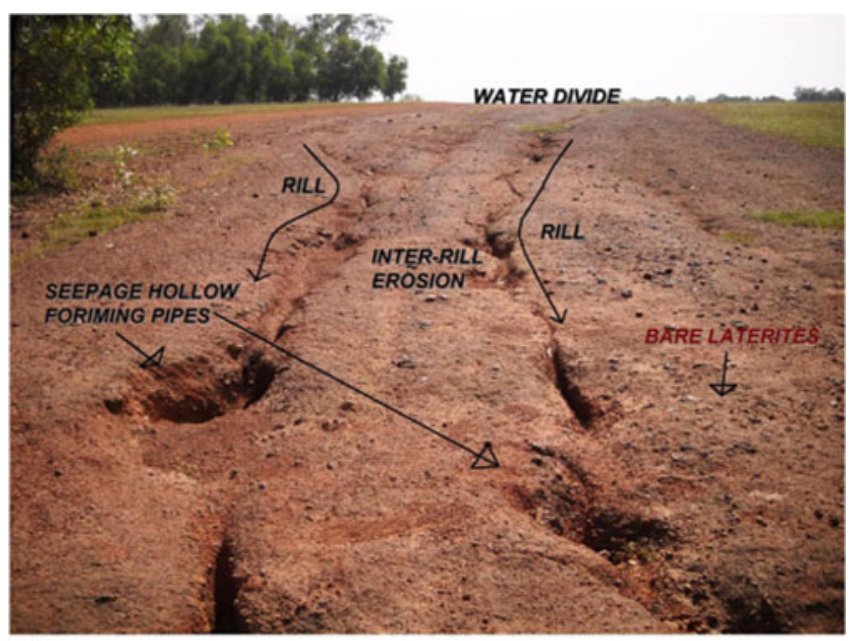

(a)

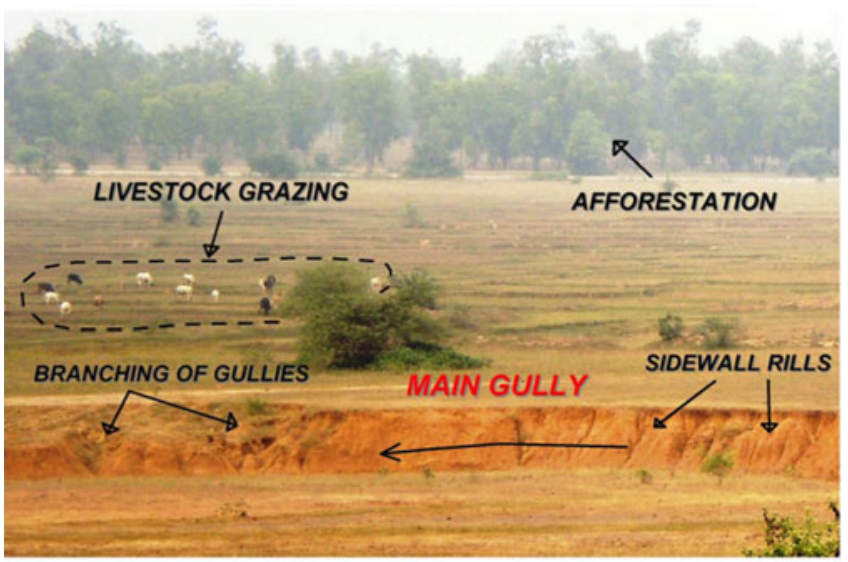

(b)

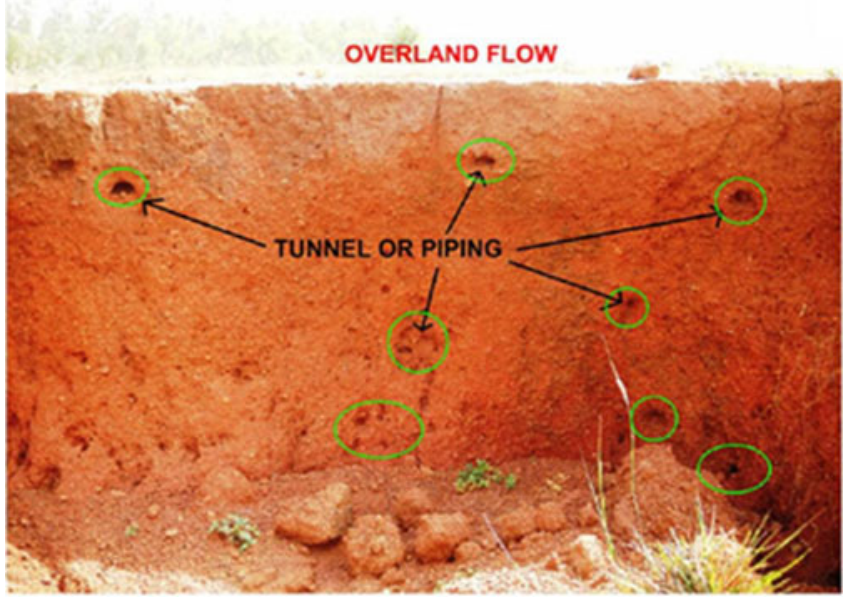

(c)

Figure 3. Photographs showing (a) rill and inter-rill erosion, (b) gully erosion and (c) tunnel erosion on laterites at western part of Bhatina village, Rampurhat. 
Table 1. Summary of land sculpturing activities in different seasons.

\begin{tabular}{lc}
\hline Climatic phenomena & Effects on landform and soil loss \\
\hline $\begin{array}{l}\text { 1. Seasonal variation of temperature } \\
\left(\text { about } 15^{\circ}-19^{\circ} \mathrm{C}\right)\end{array}$ & $\begin{array}{c}\text { Encourage various processes weathering, like block disintegration, } \\
\text { formation of cracks and joints }\end{array}$ \\
$\begin{array}{l}\text { 2. High temperature range } \\
\left.\text { (max. } 45^{\circ} \mathrm{C} \text { and min. } 9^{\circ} \mathrm{C}\right)\end{array}$ & Lowering soil moisture and ground water table, loosening of soil \\
3. Seasonal rainfall (from mid-June & peathered drying up of surface soils, reduction in soil cohesiveness \\
to 1st week of September) & ferruginous soils, laterisation process becomes active \\
4. Short phases of heavy downpour & Development of badland topography - rainsplash erosion, sheet erosion, \\
within monsoon season & rill and gully erosion, gully piping, mass wasting at gully headwall \\
& and sidewall, bareness of soil cover
\end{tabular}

Source: Sen et al. (2004), p. 213.

The climate of the study area has been identified as sub-humid and sub-tropical monsoon type, receiving mean annual rainfall of 1420-1437 mm. According to the scheme of Chorley et al. (1984), the study area is identified as 'Tropical Wet-Dry Savanna Morphogenetic Region' where the chief dominant pedo-geomorphic processes are mod-max chemical weathering, moderate physical weathering, mod-max mass wasting, max pluvial erosion, mod-max fluvial processes (sheet wash, rainsplash, rill and gully erosion-badlands), and laterisation (Cooke and Doornkamp 1987). The monsoonal and cyclonic rainfall (maximum intensity of $21.51-25.51 \mathrm{~mm} / \mathrm{hr}$ ) is the most forceful climatic variable operative in this typical lateritic badland, causing excessive erosion through rainsplash, overland flow and sub-surface flow.
According to Sen et al. (2004), there are two seasonal stages of annual soil erosion (table 1). (1) Surface preparation stage of winter (DecemberFebruary) and summer (March-May) and (2) the active surface erosion stage (mid June-October).

\section{Catchment-wise annual rainfall erosivity and aggressiveness}

Erosivity data may be used as an indicator of regional and temporal variations in erosion potential to pinpoint areas of high risk or vulnerability of erosion (Boardman et al. 2009). Soil loss is closely and directly related to rainfall partly through the detaching power (kinetic energy of raindrops) striking the bare soil surface and partly

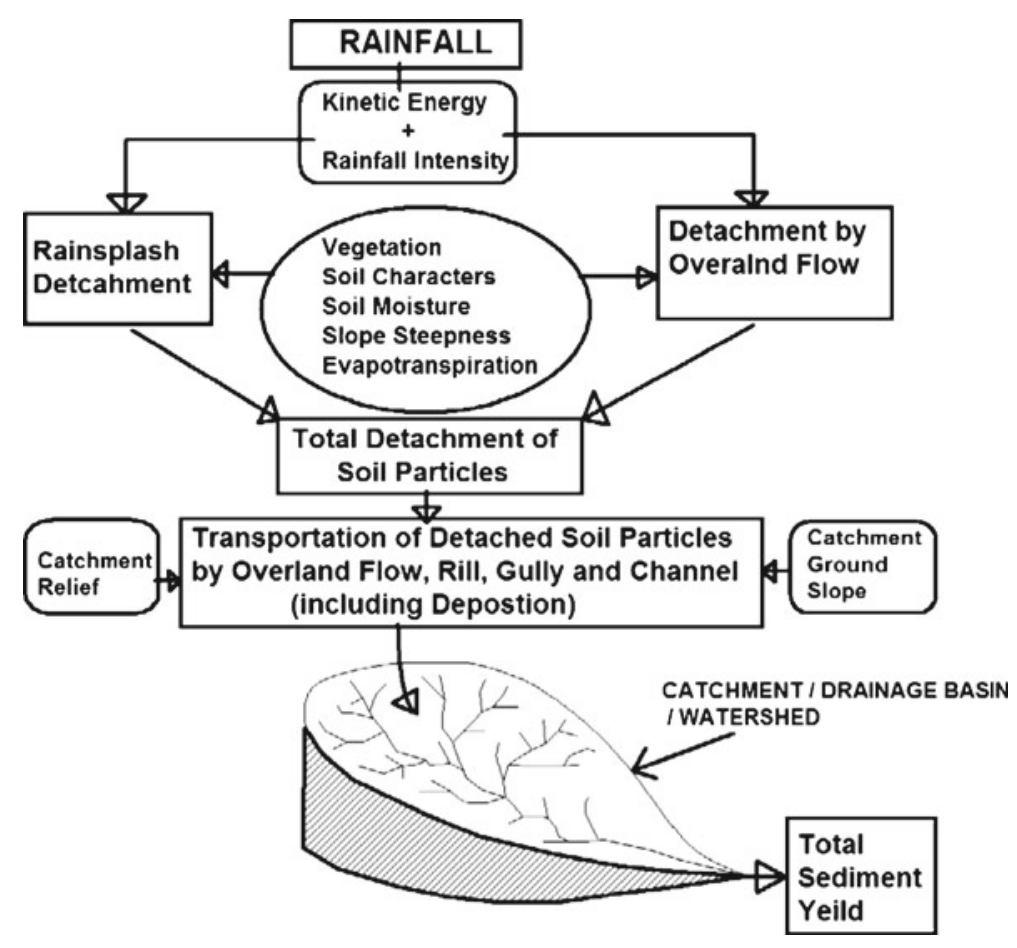

Figure 4. Simplified model of total soil loss by water from a gully-catchment. 
through the contribution of rain to surface and subsurface run-off (Morgan 2005). Due to lowcohesiveness of lateritic soil and prolonged dryness of topsoil (November-May), the study area is much more vulnerable to rainsplash erosion than overland flow in intensified monsoonal showers. In inter-rill areas, the dominant mechanism of sediment detachment is that of raindrop impact (Parsons 2005). The whole system of soil loss of a watershed is provided as model in figure 4 . To estimate the annual rainfall erosivity we have taken the average value of Roose's rainfall erosivity index (1975) and Morgan's mean annual rainfall erosivity (1974). To quantify the potential rainfall erosivity, we have employed the effective rainfall which is the actual portion of rainfall over surface after rainfall interception by vegetation. After getting the rainfall erosivity value, annual rainfall detachment of catchments (table 2) is derived by the formula of Morgan (2001). The expressions are as follows:

From (Morgan 2005), mean annual rainfall (in $\mathrm{mm})=R$ and effective rainfall $(P)=R(1-A)$ where $A$ is the proportion of rainfall interception $(0-1)$ by vegetation.

From Roose (1975), mean annual rainfall erosion index in $\mathrm{mg} \mathrm{mm} \mathrm{ha} \mathrm{h}^{-1} \mathrm{~h}^{-1}$.

From Morgan (1974), mean annual rainfall erosivity $(\mathrm{KE}>25)$

$\mathrm{I}_{30}\left(75 \mathrm{~mm} \mathrm{~h}^{-1}\right.$ - maximum value recommended by Wischmeier and Smith 1978).

From Morgan (2001), rainfall detachment rate $\left(\mathrm{kg} \mathrm{m}^{-2}\right.$ year $\left.{ }^{-1}\right)=K \mathrm{KE} 10^{-3}$, where $K$ is the soil detachability index $\left(\mathrm{g} \mathrm{J}^{-1}\right)$.

The result suggests that 2 nd order catchments of $2 \mathrm{a}, 2 \mathrm{~b}, 2 \mathrm{e}, 2 \mathrm{f}, 2 \mathrm{~g}, 2 \mathrm{~h}$ and $3 \mathrm{rd}$ order catchments of $3 \mathrm{a}, 3 \mathrm{~d}$ and $3 \mathrm{~h}$ are very much susceptible to splash erosion (figure 5). Alongside, the annual rainfall detachment rate of soil particles ranges from 1.40 to $18.12 \mathrm{~kg} \mathrm{~m}^{-2}$ year $^{-1}$. Again we have found that the catchments of loamy and clay loam soils are more prone to rainfall detachment.

Rainfall aggressiveness index (potentiality of rainfall to yield sediment from a watershed) is $\sum p^{2} / P$ (Arnolds 1980; modified form of Fournier index 1960), where $p$ is the monthly rainfall $(\mathrm{mm})$ and $P$ is annual rainfall (mm) (Morgan 2005; Parsons 2005). The high value of $\sum p^{2} / P 232.14$ and 277.33 for the years 1960 and 2008, respectively denotes a strong seasonal climatic regime with a dry season during which the plant cover decays (Morgan 2005). According to Douglas (1976), the prediction of erosion rates still rely on climatic parameters, few of which are more satisfactory than Fournier's (1960) general empirical equation embodying $p^{2} / P$, basin relief $(H)$ and basin area $(S)$ (Cooke and Doornkamp 1987). The temporal variation (1960-2006) suggests that there are increasing trend of catchment-wise sediment yield (figure 6a and 6b).

$$
\log \text { D.S. }=2.65 \log p^{2} / P+0.46 \log H^{2} / S-1.56,
$$

where D.S. is the sediment yield in ton $\mathrm{km}^{-2}$ year ${ }^{-1}$ and $H^{2}$ is coefficient of massivity.

\section{Catchment-wise overland flow and erosion risk}

The estimation of overland flow has provided an idea of volume or depth of water required for erosion and transportation in a drainage basin (Chow 1964; Chow et al. 1988). It has been found that overland flow of sample catchments is very much positively correlated with proportion of bare soil cover (0.91), constant of channel maintenance-index of watershed erodibility (0.46) and effective rainfall (0.82), and negatively correlated with actual to potential evapotranspiration ratio $(-0.95)$, effective hydrological depth of soil $(-0.92)$, ratio of soil detachment rate and transport capacity of flow $(-0.53)$ and subsurface flow $(-0.94)$, respectively.

The main erosional and transportation factor is the surface run-off of watershed which is more active on vegetation-free slopes (Kirkby 1976). With increasing proportion of bare soil cover, the moisture content and erosion protection by vegetation are reduced in this lateritic area (McFarlane 1976). In order that with rising volume of surface run-off (after Khosla 1949), the density of gullies (number of 1st order stream per $\mathrm{km}^{2}$, after Morgan 2005) is amplified (figure 6c). It has been found that 3rd order catchments have dense network of gullies than 2nd order catchments and the increasing volume of surface run-off $(X)$ is positively correlated $(r=0.82)$ with gully density $(Y)$, having increasing trend $(Y=0.0058 X+2.34)$. In the second instance (figure $6 \mathrm{~d}$ ), the low ratio of soil detachment rate and transport capacity of flow $(H / G)$ means maximum loss of soil cover from catchment (because of high transportation capacity of overland flow) which is depicted here also (figure $7 \mathrm{~b}$ ). $H / G$ ratio $(Y)$ is exponentially and negatively correlated $(r=-0.53)$ with catchmentwise overland flow $(X)$, having decreasing trend $\left(Y=506.33 X^{-1.68}\right)$.

\section{Multiple regressional analysis of sediment yield (SY) and sediment delivery ratio (SDR)}

Soil erosion is the first step in the sedimentation process which consists of fluvial erosion, transportation and deposition of sediment. A fraction of 
Erosion risk assessment of lateritic badlands of Birbhum

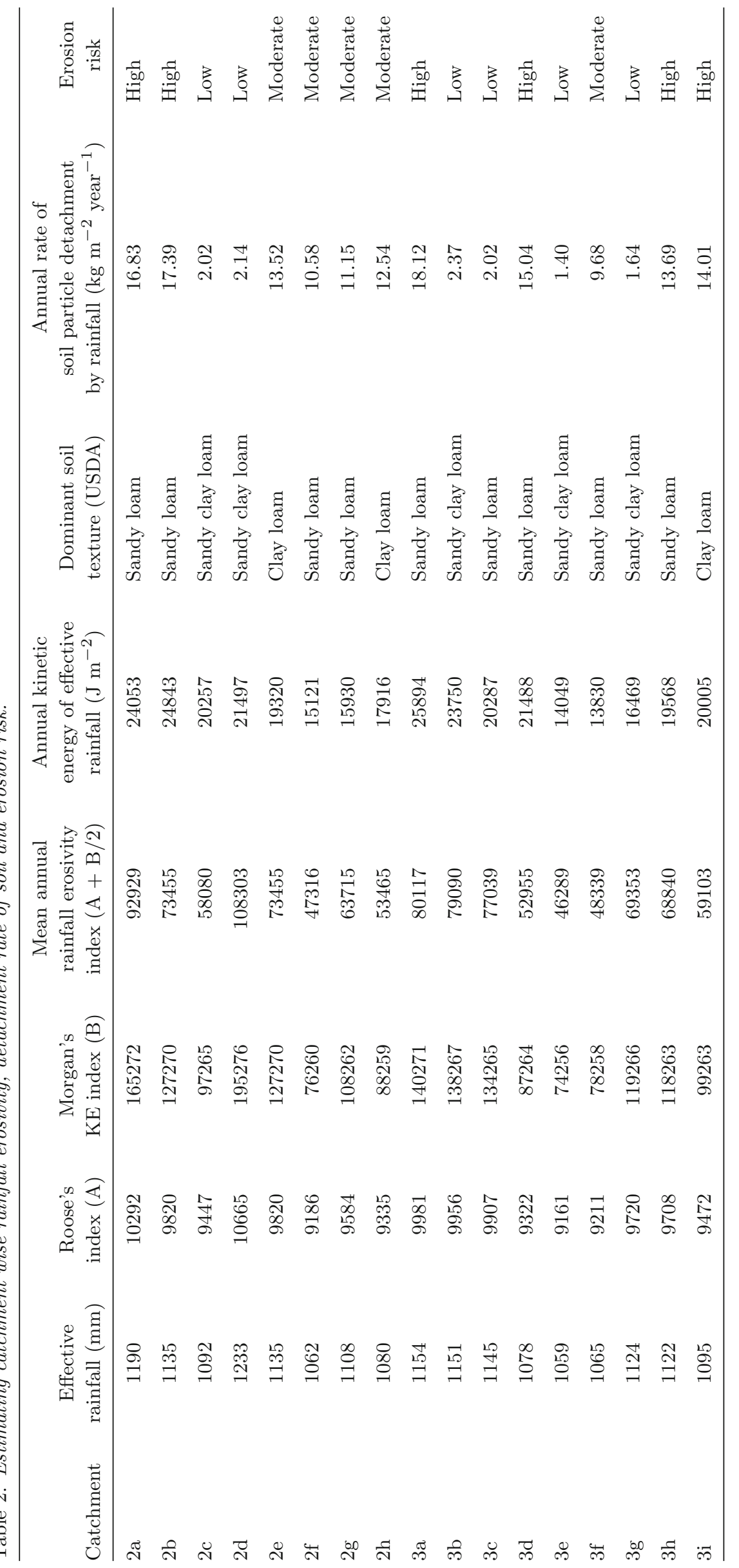




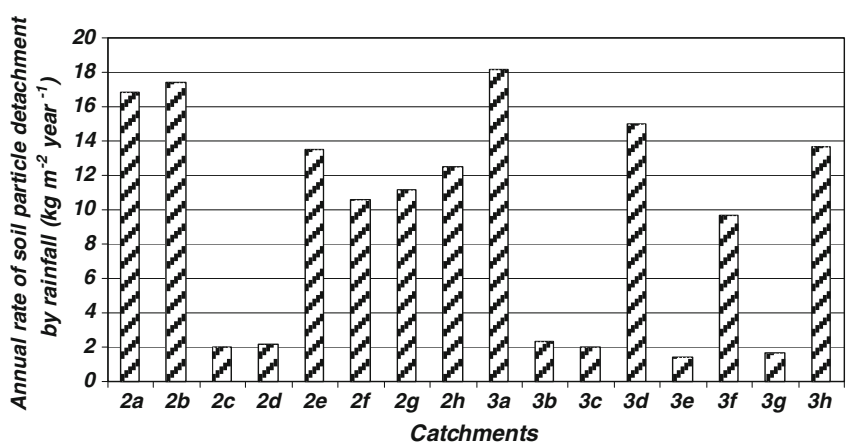

Figure 5. Diagram showing the catchment-wise annual rate of soil detachment by rainfall.

lateritic soil passes through overland flow, rills and gullies contributes to sediment yield of catchment while some of them deposit in water channels (i.e., gully floor) (Rousseva et al. 2000). Sediment yield (SY) and sediment delivery ratio (SDR) are the measure of potential erosion that takes place in a watershed, minus storage and quantifies the rate of sediment exported out of the local erosional system (Bell 1999; Wan and Sangchyoswat 2010). If we can estimate the maximum potentiality of catchments' SY and SDR, then we can rank those sample catchments into erosion risk category. Here, two predictive equations of SY and SDR are applied regionally and those equations are significantly depended on basin morphometric properties, rainfall, basin run-off, soil characters and land uses.

Douglas (1976) formulated a widely acclaimed equation of sediment yield where the numerator represents the erosive influence of rainfall and the denominator represents the vegetation-protection factor. The equation is as follows (Cooke and Doornkamp 1987):

$E=1.631(0.03937 P)^{2.3} /\left[1+0.0007(0.03937 P)^{3.3}\right]$

where $E=$ suspended sediment yield $\left(\mathrm{m}^{3} \mathrm{~km}^{-2}\right.$ year $^{-1}$ ) and $P=$ effective precipitation in $\mathrm{mm}$ (that part of the precipitation which produces surface run-off, after rainfall interception).

Using the above empirical equation, we have found the catchment-wise sediment yield rate and prepared a sediment yield map for the study area (figure 7 ). The map suggests that centrally located catchments yield more sediments and its value decreases towards south-east and north-west direction.

Again we have employed another empirical equation of sediment yield measurement using land use and hydro-geomorphic data. Universal Soil Loss Equation (USLE) estimates only sheet and rill erosion, it is necessary to incorporate the erosion by surface run-off (Wischmeier and Smith 1972; Stone and Hilbon 2000). Then combining
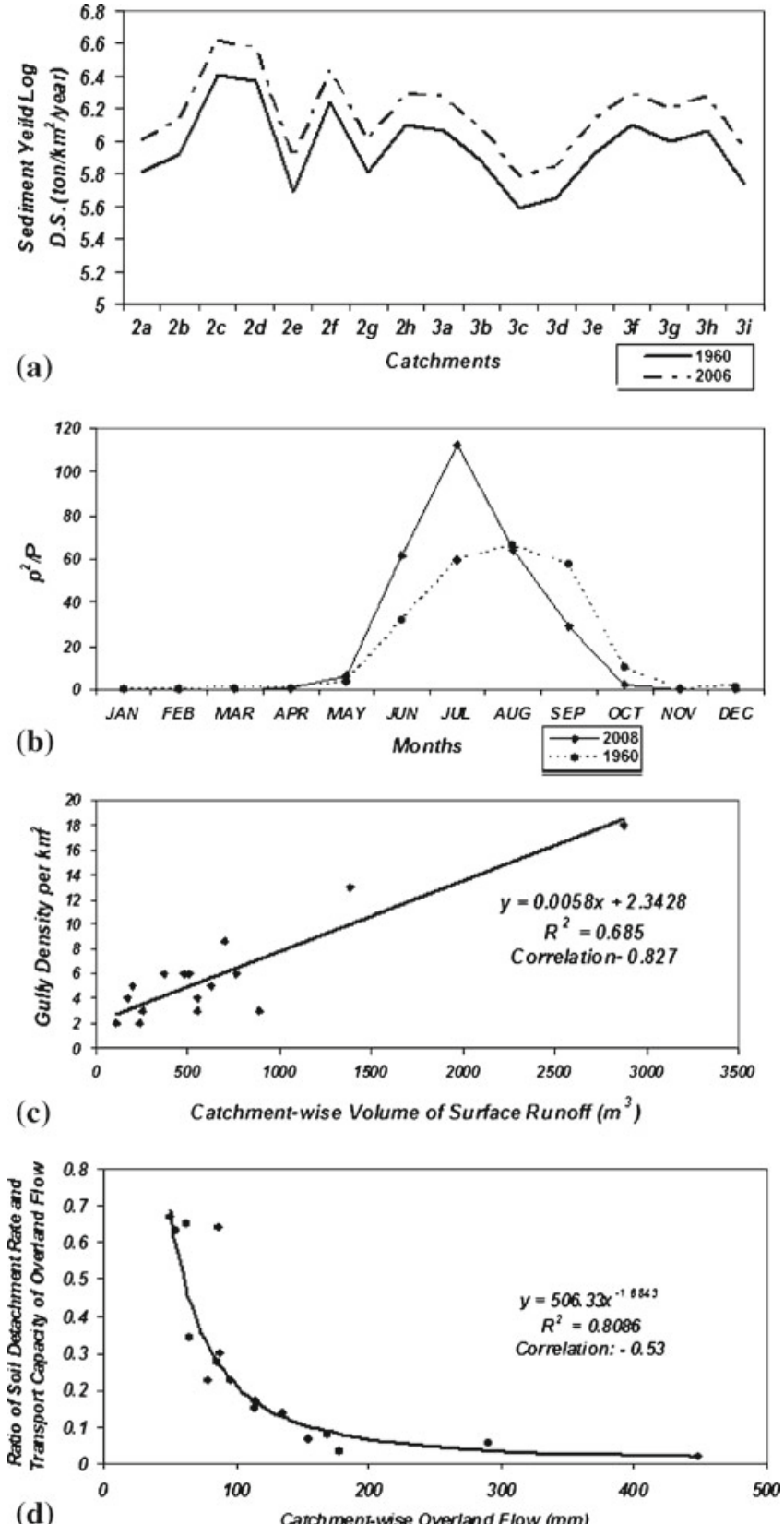

Figure 6. Diagrams showing (a) increasing sediment yield of catchments, (b) month-wise rainfall aggressiveness from the year 1960 to 2008, (c) increasing density of gully with rising volume of catchment surface run-off, and (d) decreasing ratio of soil detachment rate and transport capacity of flow (maximum soil loss) with increasing catchment overland flow.

USLE and modified USLE, Williams and Berndt (1972) have intended to quantify the sediment yield of watershed, including run-off volume and peak run-off rate. The equation is expressed as follows (Wischmeier and Smith 1978; Parsons 2005):

$$
\mathrm{SY}=11.8\left(\mathrm{Q} \mathrm{q}_{\mathrm{p}}\right)^{0.56} \mathrm{~K} \mathrm{CP} \mathrm{LS}
$$

where SY = sediment yield of monsoonal period (ton $\mathrm{km}^{-2}$ ), $\mathrm{Q}=$ run-off volume of monsoon period 

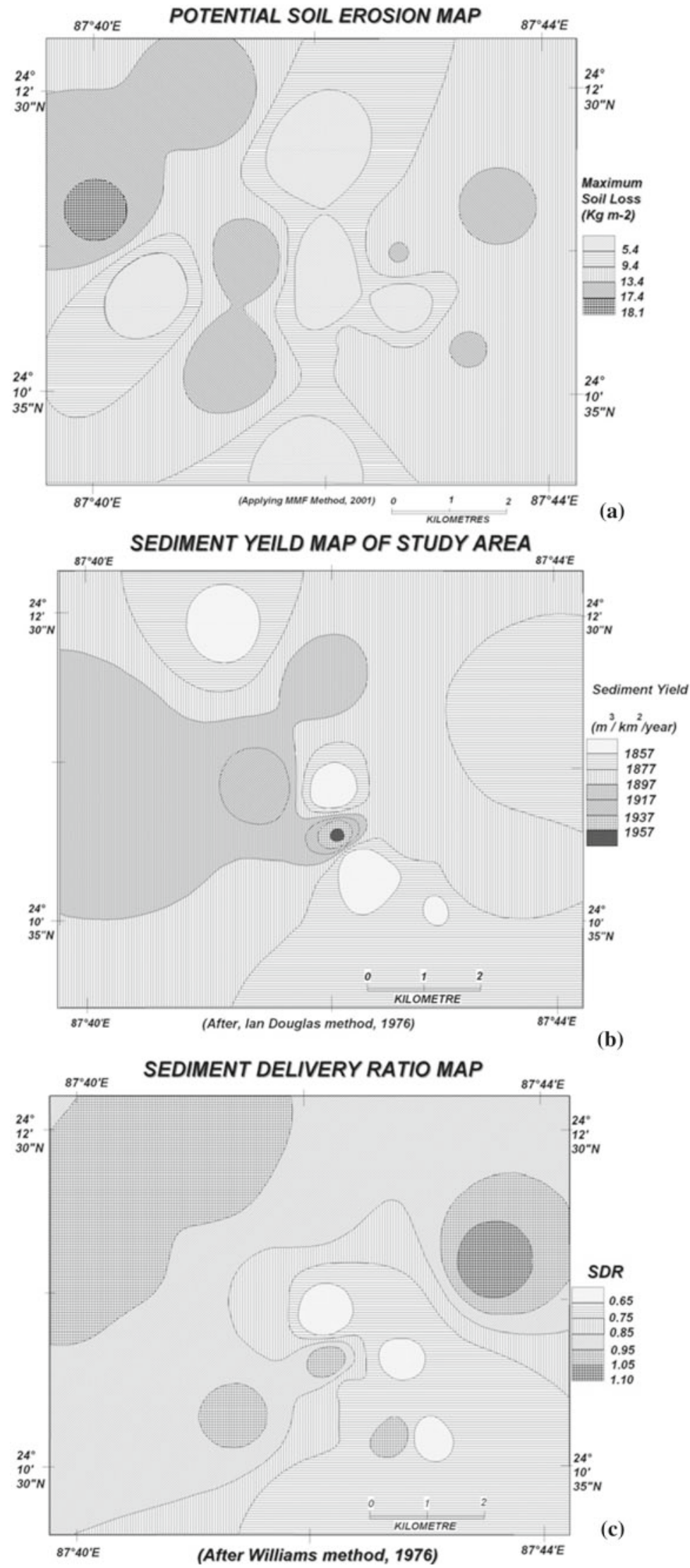

Figure 7. Maps showing (a) the total maximum potential soil loss (combination of rainsplash detachment and overland flow detachment) of the study area using Morgan's method (2001), (b) potential sediment yield of the study area and (c) sediment delivery ratio on the basis of catchments' individual values. 
Table 3. Extracting multiple linear regression of sediment yield (SY) of catchments.

\begin{tabular}{|c|c|c|c|c|c|c|}
\hline \multirow[b]{2}{*}{ Multiple regressional equation } & \multicolumn{6}{|c|}{ Unstandardized coefficients } \\
\hline & $\mathrm{a}$ & $\mathrm{b}\left(\mathrm{Q}_{\mathrm{p}}\right)$ & $\mathrm{c}(\mathrm{GD})$ & d (SED) & e $(\mathrm{H})$ & $\mathrm{f}(\mathrm{LR})$ \\
\hline $\mathrm{SY}=\mathrm{a}+\mathrm{bQ} p+\mathrm{cGD}+\mathrm{dSED}+\mathrm{eH}+\mathrm{fLR}$ & 47.938 & 9.844 & 6.478 & 0.891 & 6.073 & 67.525 \\
\hline
\end{tabular}

of catchments $\left(\mathrm{m}^{3}\right), \mathrm{q}_{\mathrm{p}}=$ peak run-off rate in monsoon of catchments $\left(\mathrm{m}^{3} \mathrm{~s}^{-1}\right), \mathrm{K}=$ soil erodibility factor of USLE, $\mathrm{C}=$ crop factor of USLE, $\mathrm{P}=$ conservation factor of USLE and LS = slope-length or topographic factor of USLE.

It has been found that monsoonal SY (after Williams and Berndt 1972) is significantly correlated (Pearson's product moment correlation, $r$ ) with the monsoonal peak discharge $\left(\mathrm{Q}_{\mathrm{p}}, r=0.95\right)$, gully density (GD, $r=0.77$ ), soil erosion density (SED, $r=0.36)$, basin relief $(\mathrm{H}, r=0.41)$ and leminscate ratio (LR, $r=-0.58$ ) of the sample catchments of this lateritic terrain. As a whole, the study area has mean SY of $191.93 \mathrm{ton} / \mathrm{km}^{2}$, mean $\mathrm{Q}_{\mathrm{p}}$ of $26.72 \mathrm{~m}^{3} / \mathrm{s}$, GD of $6 / \mathrm{km}^{2}$, and SED of $31.58 \mathrm{~km} / \mathrm{km}^{2}$. From the analysis we have prepared a multiple regressional equation (table 3 ) $\mathrm{SY}=-47.938+9.844 \mathrm{Q}_{\mathrm{p}}+6.478 \mathrm{GD}-0.891 \mathrm{SED}-$ $6.073 \mathrm{H}+67.525 \mathrm{LR}$. The multiple regression estimates that 2a, 2b, 2c, 3a, 3b, 3c, 3d and $3 \mathrm{i}$ catchments have high potentiality of sediment yield in the heavy monsoon period (June to September).

Sediment delivery ratio (SDR) is the ratio between sediment yield and gross erosion per unit area above a measuring point. SDR is expressed as a percent and represents the efficiency of the catchment in moving soil particles from the areas of erosion to the point where sediment yield is measured. According to Williams (1977), SDR (figure 9b) is estimated as follows (Wischmeier and Smith 1978; Morgan 2005):

$$
\mathrm{SDR}=1.36610^{-11}(\mathrm{DA})^{-0.0998}(\mathrm{ZL})^{0.3629}(\mathrm{CN})^{5.444}
$$

where DA = drainage area in $\mathrm{km}^{2}$, ZL = relieflength ratio in metre $\mathrm{km}^{-1}, \mathrm{CN}=$ curve number of run-off (Chow et al. 1988).

Table 4. Extraction of three principal components of selected variables of catchments and their relative dominance.

\begin{tabular}{|c|c|c|c|c|}
\hline Variables & Source & PC1 & $\mathrm{PC} 2$ & $\mathrm{PC} 3$ \\
\hline Effective rainfall (mm) & Morgan (2005) & 0.87655 & 0.27468 & 0.16832 \\
\hline Run-off coefficient & Chow (1964) & 0.94351 & 0.219 & 0.01179 \\
\hline Overland flow (mm) & Kirkby (1976) & 0.94351 & 0.219 & 0.01179 \\
\hline Subsurface flow (mm) & Kirkby (1976) & -0.9335 & -0.2226 & -0.147 \\
\hline Rainfall erosivity & Morgan (2005) & 0.74697 & -0.1466 & 0.02439 \\
\hline Actual to potential evapotranspiration $\left(\mathrm{E}_{\mathrm{t}} / \mathrm{E}_{\mathrm{o}}\right)$ & Morgan (2005) & -0.9597 & -0.2443 & -0.0119 \\
\hline Effective hydrologic depth of soil in metre (EHD) & Morgan (1987) & -0.9436 & -0.0752 & -0.1432 \\
\hline Soil moisture $\left(\mathrm{R}_{\mathrm{c}}\right)$ & Kirkby (1976) & -0.9784 & -0.1774 & -0.0713 \\
\hline Proportion of bare soil cover & & 0.83233 & 0.34317 & 0.02285 \\
\hline Crop factor & Morgan (2005) & 0.81808 & 0.35882 & 0.05174 \\
\hline $\begin{array}{l}\text { Ratio of soil detachment rate and transport capacity } \\
\text { of flow }(\mathrm{H} / \mathrm{G})\end{array}$ & Morgan (2005) & -0.6891 & -0.1321 & -0.2089 \\
\hline Surface run-off volume in $\mathrm{m}^{3}$ & Khosla (1949) & 0.34096 & -0.7637 & 0.42739 \\
\hline Monsoonal peak discharge $\mathrm{m}^{3} / \mathrm{s}$ & Kirkby (1976) & 0.34096 & -0.7637 & 0.42739 \\
\hline Drainage density $\mathrm{D}_{\mathrm{d}}$ & Horton (1945) & -0.4196 & 0.61991 & 0.4312 \\
\hline Length of overland flow $\mathrm{L}_{\mathrm{g}}$ & Horton (1945) & 0.47545 & -0.2545 & -0.3716 \\
\hline Constant of channel maintenance (C) & Schumm (1956) & 0.56804 & -0.501 & -0.4429 \\
\hline Gully density $/ \mathrm{km}^{2}$ (GD) & Morgan (2005) & 0.10729 & -0.7316 & 0.57561 \\
\hline Soil erosion density $/ \mathrm{km}^{2}$ (SED) & Morgan (2005) & -0.1571 & -0.3804 & 0.71779 \\
\hline Catchment relief in metre & Chorley (1969) & -0.0147 & -0.2748 & 0.74574 \\
\hline Relief/length ratio & Chorley (1969) & -0.2682 & 0.72738 & 0.40221 \\
\hline Maximum valley-side slope $\theta_{\max }$ & Melton (1958) & -0.2692 & 0.42018 & 0.61325 \\
\hline Mean ground slope of catchment $\mathrm{S}_{\mathrm{g}}$ & Chorley (1969) & -0.2544 & 0.64594 & 0.30978 \\
\hline Leminscate ratio & Chorley et al. (1984) & -0.2493 & 0.91359 & 0.0622 \\
\hline Eigen value & & 9.848671 & 5.182548 & 3.049189 \\
\hline$\%$ of Variance & & 42.82031 & 22.53282 & 13.25734 \\
\hline Cumulative variance $\%$ & & 42.82031 & 65.35312 & 78.61047 \\
\hline
\end{tabular}


From the sediment delivery ratio map (figure 7), we have found that the delivery of sediment is decreasing from north-west to south-east direction whereas western and central portions of the study area have generated maximum sediment yield. From the result it can be predicted that 2 nd order catchments of $2 \mathrm{a}, 2 \mathrm{~b} 2 \mathrm{~d}$ and $3 \mathrm{rd}$ order catchments of $3 \mathrm{a}, 3 \mathrm{~b}, 3 \mathrm{c}, 3 \mathrm{~d}$ and $3 \mathrm{i}$ have generated high value of SDR (0.85-1.10) in respect of hydro-geomorphic parameters. So those areas of catchments should be protected from soil detachment and sediment transportation.

\section{Factor analysis and categorization of erosion risk}

In multivariate analysis of geomorphic phenomena, often volumes of data having many variables are analysed amidst the problem of multidimensionality. Multidimensionality is signified by a condition wherein groups of variables often move together and one reason for this is that more than one variable may be measuring the same driving principle governing the behaviour of the system (Singh 2007). According to Kothari (2009), the factor analysis is a multivariate technique to find out something more fundamental among interdependent variables or latent which creates the commonality.

Though rainfall detachment and detachment by overland flow are the main source of sediment yield of catchment, both of them are controlled by numerous climatic, hydro-geomorphic and pedologic variables of catchment (Shrestha 1997; Boardman et al. 2009). So to reduce the number of variables into few factors or components and to detect structure in the inter-relationships among variables we have employed principal component analysis (PCA) which is a method of factor analysis. The principal components (PC) as whole form an orthogonal basis for the space of the data (Gregory 1977; Singh 2007). Considering 20 variables of 17 sub-catchments (2nd and 3rd orders), we have extracted the principal components in such a fashion that first PC accounts for the largest amount of total variation in the data (table 4). The importance of each component is expressed by its eigen values. The higher the eigen value, the more important is the component because of the largest number of inter-correlated dominant parameters (Singh 2007; Kothari 2009). Transforming the first and second $\mathrm{PC}$ into prinsscores and then into Z-scores, we have standardized and categorized the sample catchments into susceptibility of fluvial erosion in relation to dominant hydro-geomorphic variables (Doornkamp and King 1971; Gregory 1977). Alongside, discriminate analysis is used to understand the association and separation of the catchments from each other based on Z-scores. The main purpose of discriminate analysis is to cluster the groups of catchments which are discriminated from other groups based on scores of erosion risk.

We have chosen 20 important variables which inter-relatedly contribute their negative and positive effects on the whole system of catchment denudation. Extracting three principal components

Table 5. Transforming the 1st and 2nd principal components to individual catchments' prinsscores, Z-scores and their ranking of erosion risk.

\begin{tabular}{|c|c|c|c|c|c|c|}
\hline Gully-catchment & $\begin{array}{c}\text { Prinsscore } \\
\text { PC } 1\end{array}$ & $\begin{array}{l}\text { Prinsscore } \\
\text { PC } 2\end{array}$ & $\begin{array}{l}\text { Total } \\
\text { score }\end{array}$ & $\begin{array}{l}\text { Rank (high to low } \\
\text { erosion risk) }\end{array}$ & Z-score $_{1}$ & Z-score $_{2}$ \\
\hline $2 \mathrm{a}$ & 2001.58 & -735.44 & 2737.02 & 3 & 1.300 & -0.855 \\
\hline $2 \mathrm{~b}$ & 2002.14 & -726.97 & 2729.11 & 2 & 1.302 & -0.802 \\
\hline $2 \mathrm{c}$ & 1618.3 & -536.61 & 2154.91 & 6 & 0.045 & 0.382 \\
\hline $2 \mathrm{~d}$ & 1765.76 & -546.14 & 2311.9 & 4 & 0.528 & 0.323 \\
\hline $2 \mathrm{e}$ & 1575.02 & -574.7 & 2149.72 & 9 & -0.097 & 0.145 \\
\hline $2 \mathrm{f}$ & 1223.03 & -411.45 & 1634.48 & 14 & -1.250 & 1.161 \\
\hline $2 \mathrm{~g}$ & 1298.05 & -435.62 & 1733.67 & 13 & -1.004 & 1.010 \\
\hline $2 \mathrm{~h}$ & 1440.71 & -494.76 & 1935.47 & 10 & -0.537 & 0.642 \\
\hline $3 a$ & 2092.82 & -782.95 & 2875.77 & 1 (Highest) & 1.599 & -1.150 \\
\hline $3 b$ & 1926.2 & -706.78 & 2632.98 & 5 & 1.053 & -0.676 \\
\hline $3 c$ & 1736.93 & -962.3 & 2699.23 & 15 & 0.433 & -2.267 \\
\hline $3 d$ & 1737.8 & -674.71 & 2412.51 & 7 & 0.436 & -0.477 \\
\hline $3 e$ & 1152.04 & -430.91 & 1582.95 & 17 (Lowest) & -1.482 & 1.040 \\
\hline $3 \mathrm{f}$ & 1124.08 & -371.32 & 1495.4 & 16 & -1.574 & 1.411 \\
\hline $3 \mathrm{~g}$ & 1347.05 & -469.68 & 1816.73 & 12 & -0.843 & 0.798 \\
\hline $3 \mathrm{~h}$ & 1583.35 & -575.24 & 2158.59 & 8 & -0.069 & 0.142 \\
\hline $3 \mathrm{i}$ & 1651.8 & -731.25 & 2383.05 & 11 & 0.154 & -0.829 \\
\hline
\end{tabular}


we have cumulatively explained $78.61 \%$ of total variance, having three eigen values $9.84,5.18$ and 3.04, respectively. The three principal components uniquely dominated the system are as follows:

- PC 1: Mainly climatic and hydrologic variables drive strongly the denudation system of catchments; effective rainfall, run-off coefficient, overland flow, rainfall erosivity, bare soil cover and crop factor positively influence the system; whereas sub-surface flow, $\mathrm{E}_{\mathrm{t}} / \mathrm{E}_{\mathrm{o}}, \mathrm{EHD}, \mathrm{R}_{\mathrm{c}}$ and $\mathrm{H} / \mathrm{G}$ negatively influence the system.

- PC 2: Mainly geomorphic variables, viz., leminscate ratio, catchment ground slope, relief/length ratio and gully density drive system; though runoff volume and monsoonal peak discharge have an effect in the motion of system.

- PC 3: Again geomorphic variables, viz., gully density, SED, catchment relief and $\theta_{\max }$ drive the denudation system positively.

Based on the summation of prinsscores of PC1 and $\mathrm{PC} 2$, we have ranked the gully-catchments

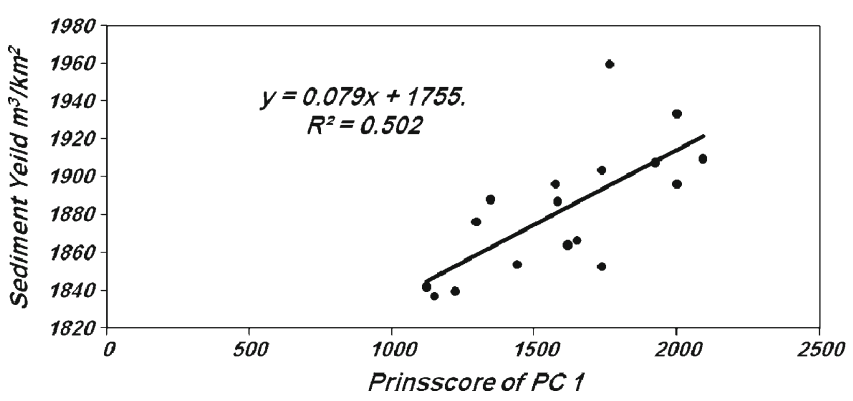

Figure 8. The postive linear trend line is established between catchment-wise prinsscore of $\mathrm{PC} 1(\mathrm{x})$ and potential sediment yield of catchments $(\mathrm{y})$.

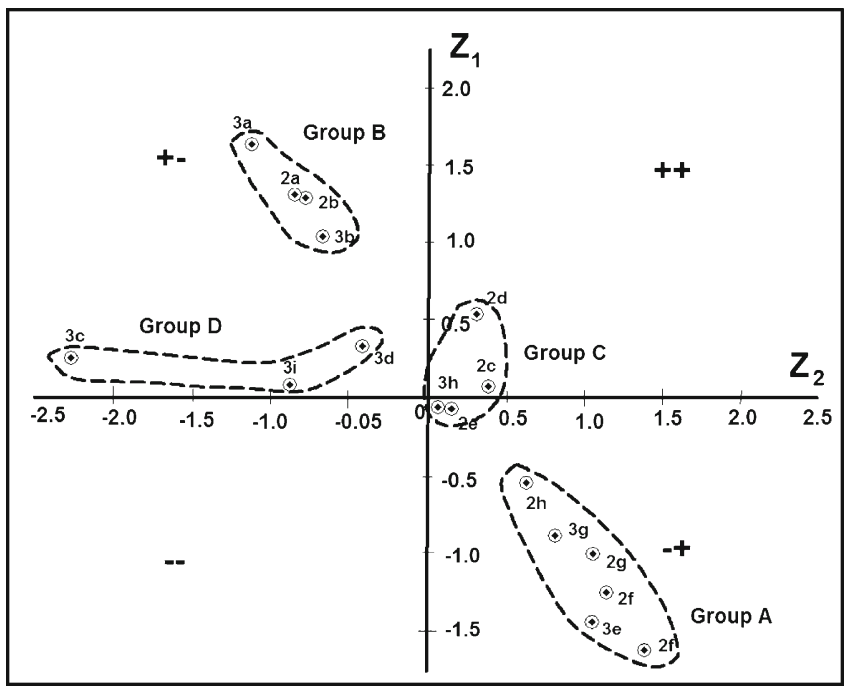

Figure 9. Discriminate analysis showing four clusters of catchments on the basis of $\mathrm{Z}$ scores. (table 5) into high to low erosion risk which are positively correlated with potential sediment yield rate of the sample catchments (figure 8).

Based on the dendogram of catchments' prinsscores (similarity coefficients), we have obtained at least four clusters of catchments. Then from the discriminate analysis of Z-score ${ }_{1}\left(\mathrm{Z}_{1}\right)$ and Z-score 2 $\left(Z_{2}\right)$ we have categorized the four groups of catchments (figures 9 and 10) on the basis of individual performance of hydro-geomorphic variables (table 5). So those groups have unique property of erosional system in this lateritic terrain and the priority of soil conservation should be given on this basis. Groups B and A have high risk of soil erosion than two other groups, so the catchments of Gr. A and Gr. B should get main concern

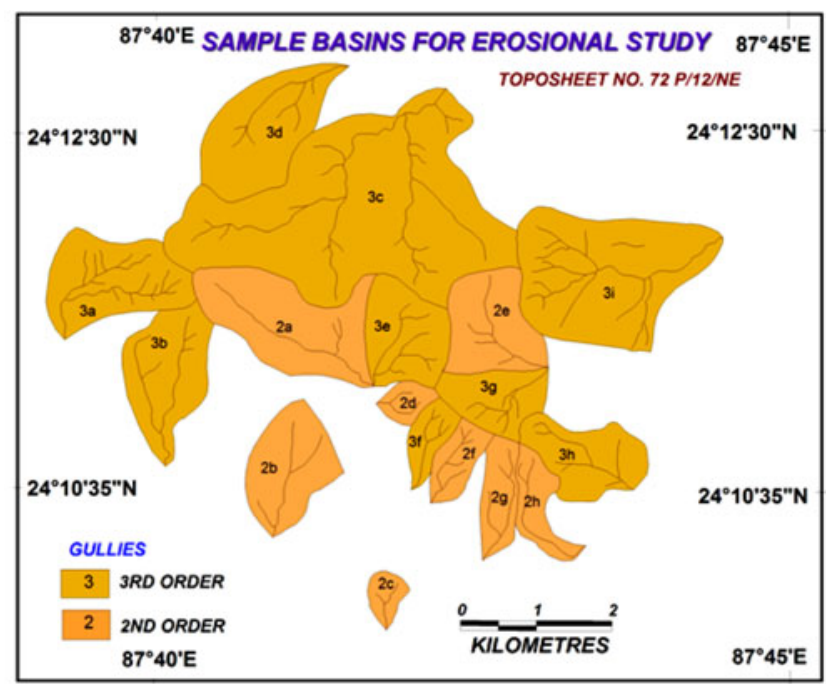

(a)

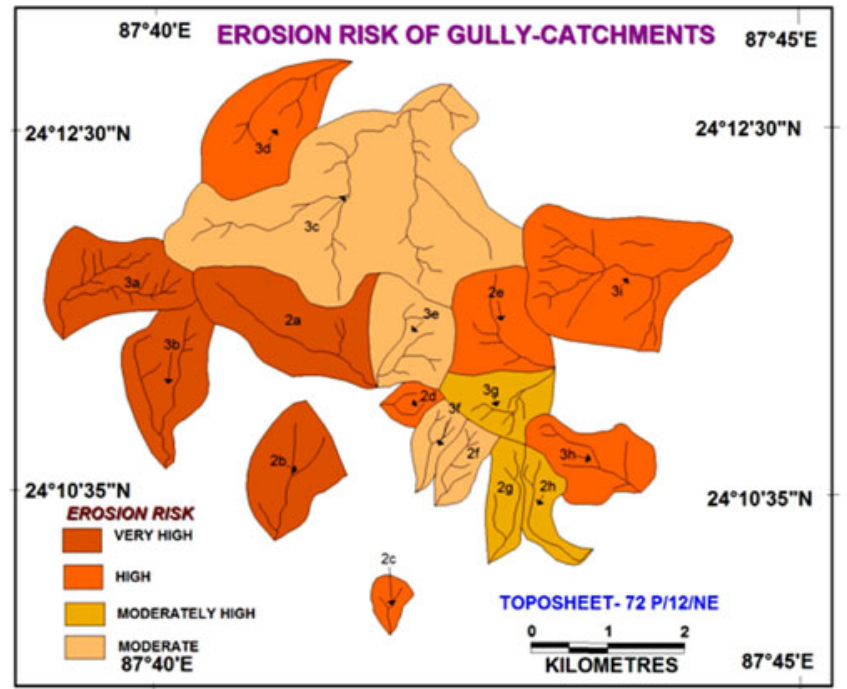

(b)

Figure 10. Maps representing (a) sample gully catchments of 2 nd and 3rd orders and (b) categorization of gullycatchments into erosion risk. 
Table 6. Categorizing risk and priority of catchments on the basis of erosional properties.

\begin{tabular}{llcccccc}
\hline Group & \multicolumn{1}{c}{ Catchments } & $\begin{array}{c}\text { Mean overland } \\
\text { flow }(\mathrm{mm})\end{array}$ & $\begin{array}{c}\text { Mean potential } \\
\text { erosion }\left(\mathrm{kg} / \mathrm{m}^{2}\right)\end{array}$ & $\begin{array}{c}\text { Mean } \\
\text { SDR }\end{array}$ & $\begin{array}{c}\text { Mean SY } \\
\left(\mathrm{ton} / \mathrm{km}^{2}\right)\end{array}$ & $\begin{array}{c}\text { Mean gully } \\
\text { density } / \mathrm{km}^{2}\end{array}$ & $\begin{array}{c}\text { Priority } \\
\text { rank }(\mathrm{risk})\end{array}$ \\
\hline A & 2c, 2d, 2e, 3d, 3h, 3i & 130.28 & 10.11 & 0.87 & 149.78 & 6.50 & II (High) \\
B & 2a, 2b, 3a, 3b & 237.82 & 16.24 & 0.94 & 182.71 & 8.33 & I (Very high) \\
C & 2f, 3c, 3e, 3f & 53.17 & 7.23 & 0.67 & 43.05 & 5.00 & IV (Moderate) \\
D & 2g, 2h, 3g & 82.86 & 8.46 & 0.67 & 145.26 & 7.33 & III (Moderately high) \\
\hline
\end{tabular}

for soil conservation and for minimization of dominant hydro-geomorphic variables (table 6). Therefore, each individual group is treated as unique conservational measures to minimize the effect of dominant variables and to maximize the resistance of soil.

\section{Conclusion}

The diagnostic survey and multivariate analysis of different aspects of gully erosion of sample basins, developed in the reddish brown coloured lateritic tract of western Rampurhat I Block, have revealed the exact controlling factors of soil loss and the spatial variation of erosion. The employed methods and techniques are very much fruitful here to extract significant information from the complex data. Considering the importance of rainfall erosivity, catchment overland flow and soil erodibility, we have obtained success to incorporate the other influencing factors or components which can enhance the soil erosion of the gully catchments differentially. Comparatively, the hydrologic variables are very much influenced by the denudational system than the geomorphic variables. Understanding and estimating the potential soil erosion, sediment yield and sediment delivery ratio, at last we have identified category of sample catchments into different magnitude of erosion risk. So the multivariate analysis has produced an erosional individuality of each catchment in this small spatial unit and it can be considered as an aid for the special conservational treatment of each erosion prone catchment.

In general due to infertility, shallowness and low water holding capacity of lateritic soil and cementation of ferruginous concretions of iron oxide colloids, there is limited supply of soil moisture and limited growth of trees except shrubs, open scrub and thin grasses. These factors transform the land as degraded barren waste and dissected badlands. The other important observable factors of longterm excessive soil loss are high rainfall erosivity of short period, deforestation (due to basalt quarrying), morum quarrying, livestock grazing, elevated metal roads and long stretch of concrete basement (Sijua Aerodrome). Though, with the recent implementation of 'Bhatina Watershed Management Program' the forest cover is increased by plantation but the grass cover and newly grown plants of lateritic uplands and gully floors should be protected from grazing activity to avoid further gully expansion.

\section{References}

Abrahams A D (ed.) 1964 Hillslope Hydrology (Boston: Allen and Unwin), pp. 16-38.

Arnolds A 1980 Lupinurannsoknir Rannsoknastofnun Landbunaoarins; Report 59.

Bell F G 1999 Geological hazards: Their assessment, avoidance and mitigation, E and Fn Spon, London, pp. 11-13, 396-440.

Blinkov I and Kostadinov S 2010 Applicability of various erosion risk assessment methods for engineering purposes: http://-balwois.com/balwois/administration/full_paper/ ffp-1693.pdf.

Boardman J, Shepheard M L, Walker E and Foster I D L 2009 Soil erosion and risk-assessment for on- and offfarm impacts: A test case using the Midhurst area, West Sussex, UK; J. Environ. Manag. 90(8) 1-11.

Chorley R J 1969 The drainage basin as the fundamental geomorphic unit; In: Water, Earth and Man (ed.) Chorley R J (London: Methuen), pp. 77-98.

Chorley R J, Schumm S A and Sugden D E 1984 Geomorphology (London: Methuen), pp. 316-324.

Chow V T (ed.) 1964 Handbook of Applied Hydrology (New York: McGraw-Hill Book Company), pp. 4-39-4-72.

Chow V T, Maidment D R and Mays L W 1988 Applied Hydrology (New York: McGraw-Hill Book Company), pp. 147-152, 496-502.

Cooke R U and Doornkamp J C 1987 Geomorphology in Environmental Management, Clarendon Press, Oxford.

Doornkamp J C and King C A M 1971 Numerical Analysis in Geomorphology (New York: St. Martin's Press), pp. $1-98$.

Douglas I 1976 Erosion rates and climate: Geomorphological implications; In: Geomorphology and Climate (ed.) Derbyshire E (London: John Wiley and Sons), pp. 269-284.

Fournier F 1960 Climat et erosion: La relation entre l'erosion du sol par l'eau et les precipitations atmospheriques; Presses Universitaries de France.

Gerrard A J 1981 Soils and landforms: An integration of geomorphology and pedology (London: George Allen and Unwin), pp. 16-60.

Gregory S 1977 Statistical Methods and the Geographers (New York: Longman Scientific and Technical), pp. 47-48.

Horton R E 1945 Erosional development of streams and their drainage basins: Hydrophysical approach to quantitative morphology; Geol. Soc. Am. Bull. 56 275370. 
Hudson N 1984 Soil Conservation; (London: English Language Book Society), pp. 62-87, 113-127.

Hundy A and Banerjee S 1967 Geology and mineral resources of West Bengal; Memoirs of the GSI, Delhi 97 $44-54$.

Jha M K and Paudel R C 2010 Erosion predictions by empirical models in a mountainous watershed in Nepal; J. Spatial Hydrol. 10(1) 89-102.

Jha V C and Kapat S 2009 Rill and gully erosion risk of lateritic terrain in south-western Birbhum District, West Bengal, India; Sociedade \& Natureza, Uberlândia 21(2) 141-158.

Khosla A N 1949 Analysis and utilization of data for the appraisal of water resources; The Central Board of Irrigation and Power Journal, Delhi 6(4) 410-422.

Kothari C R 2009 Research Methodology (New Delhi: New Age International Publishers), pp. 315-340.

Kirkby M J 1969a Erosion by water on hillslopes; In: Water, Earth and Man (ed.) Chorley R J (London: Methuen), pp. 229-238.

Kirkby M J 1969b Infiltration, through flow and overland flow; In: Water, Earth and Man (ed.) Chorley R J (London: Methuen), pp. 215-226.

Kirkby M J 1976 Hydrological slope models: The influence of climate; In: Geomorphology and Climate (ed.) Derbyshire E (London: John Wiley and Sons), pp. 247-266.

McFarlane M J 1976 Laterite and Landscape (London: Academic Press), pp. 91-108.

Melton M A 1958 Geometric properties of mature drainage systems and their representation in an E4 phase space; J. Geol. 66 35-54.

Morgan R P C 1974 Estimating regional variations in soil erosion hazard in Peninsular Malaysia; Malay Nature Journal 28 94-106.

Morgan R P C 1987 A system approach to conservation tillage; Experimental Agriculture 23(1) 107.

Morgan R P C 2001 A simple approach to soil loss prediction: A revised Morgan-Morgan-Finney Model; Catena 44 305-322.

Morgan R P C 2005 Soil Erosion and Conservation (Malden: Blackwell Publishing), pp. 67-157.

Morisawa M 1985 Rivers: Form and processes; Longman, London.

Parsons A J 2005 Erosion and sediment transport by water on hillslopes; In: Encyclopedia of Hydrological Sciences (ed.) Anderson M G (New York: John Wiley and Sons Ltd), pp. 1199-1205.

Roose E J 1975 Natural mulch or chemical conditioners for reducing soil erosion in humid tropical area; Soil Science Society of Civil Engineers 98 2087-2098.
Rousseva S, Lazarov A, Stefanova V and Malinov I 2000 Soil Erosion Risk Assessments in Bulgaria; http://-balwois.com/balwois/administration/full_paper/ ffp-608.pdf.

Sarkar D, Dutta D, Nayak D C and Gajbhiye K S et al. 2005 Soil erosion of West Bengal; National Bureau of Soil Survey and Land Use Planning, NBSS Publ. 117, Nagpur.

Sarkar D, Dutta D, Nayak D C and Gajbhiye K S 2007 Optimizing land use of Birbhum District (West Bengal) soil resource assessment; National Bureau of Soil Survey and Land Use Planning, NBSS Publ., Nagpur, 130 1-33.

Schumm S A 1956 Evolution of drainage systems and slopes in badlands at Perth Amboy; Geol. Soc. Am. Bull. 67 $597-646$.

Sen J, Sen S and Bandyopadhyay S 2004 Geomorphological investigation of badlands: A case study at Garhbeta, West Medinipur District, West Bengal, India; In: Geomorphology and Environment (eds) Singh S, Sharma H S and De S K (Kolkata: ACB Publication), pp. 204-234.

Shrestha D P 1997 Assessment of soil erosion in the Nepalese Himalaya: A case study in Likhu Khola Valley, Middele Mountain Region; Oxford \& IBH Publishing Co. Pvt. Ltd, Land Husbandry 2(1) 59-80.

Singh K 2007 Quantitative Social Research Methods; Sage Publications, Los Angeles, pp. 202-213.

Stoddart D R 1969 World erosion and sedimentation; In: Water, Earth and Man (ed.) Chorley R J (London: Methuen), pp. 43-63.

Stone R P and Hilbon D 2000 Universal Soil Loss Equation; Factsheet, Ministry of Agriculture, Food and Rural Affairs, Ontario.

Wan Z and Sangchyoswat C 2010 Soil erosion risk assessment using GIS and Farmer's Perception: A case study in dry zone area of central region of Myanmar; http://www.mcc.cmu.ac.th/Seminar/pdf/1534.pdf.

Williams J R and Berndt H D 1972 Sediment yield computed with universal equation; Proc. Am. Soc. Civil Engineers 98 2087-2098.

Williams J R 1977 Sediment delivery ratios determined with sediment and runoff models; Int. Assoc. Hydrol. Sci. Publ. 122 168-179.

Wischmeier W H and Smith D D 1972 Predicting rainfallerosion losses from cropland and east of the Rocky Mountains, USDA; Agriculture Handbook No. 282, Washington, pp. 1-43.

Wischmeier W H and Smith D D 1978 Predicting rainfall-erosion losses: A guide to conservation planning, USDA; Agriculture Handbook No. 537, Washington, pp. 1-32. 